УДК 78.089 : 792.8 "ХІХ"

DOI:10.15330/esu.14.45-51
Людмила Мова,

докторант, Національний педагогічний університет імені М. П. Драгоманова

(м. Київ, Україна)

Liudmyla Mova,

Doctoral Candidate, National Pedagogical Dragomanov

University (Kiev, Ukraine)

RV221a@meta.ua

\title{
РОЗВИТОК МУЗИЧНИХ ФОРМ У ХОРЕОГРАФІЧНОМУ МИСТЕЦТВІ ДРУГОЇ ПОЛОВИНИ ХХ СТОЛІТТЯ
}

\section{THE DEVELOPMENT OF MUSICAL FORMS IN CHOREOGRAPHIC ART IN THE SECOND HALF OF THE XXth CENTURY}

Стаття присвячена питанням формоутворення у музично-хореографічних виставах другої половини ХХ століття. Проаналізовано співпрачю Джона Кейджа та Мерса Каннінгема в мистечтві танчю. Автор розкриває основні типи музичних форм (мобільна форма та модульна форма) та методи взасмодії, які характеризувалися для таниів постмодериу. Також висвітлена роль імпровізачіӥ в хореографічному мистечтві.

Показано, ио існують специфічні методи створення / натисання музичної композичї та принцити формувания в постмодерністському таниі. Найбільи важливими серед них е творчий принцип індетермінізму і метод випадкової дії, які стали основою музичнохореографічних вистав і творів чистої інструментальної музики другої половини ХХ століття. Основною характеристикою танџювальних вистав е свобода формування форм. Композитори, які прачювали в постмодерністському таниі, використовують алеаторні форми для пошуку нових структурних рімень органічного посднания з вільними хореографічними композичіями з академічним кліие. Композитори та хореографи вважають, ио головним художнім завданиям с перехід мистечької роботи з об'скта в прочес.

Ключові слова: танечь постмодерн, музично-хореографічний перфоманс, алеаторичні форми.

The article is devoted to the issues of form-generation in the musical choreographic perfomances in the second half of the $X X$ century. The cooperation between John Cage and Merce Cunningham in the dance art is analysed. The author lists up the main types of music forms (mobile form and modular form) and methods of the interaction, which were characterized for the dances of Postmodern period. The role of the improvisation in dance is highlighted.

Thus, there are specific methods for creating / writing a musical composition and the principles of forming in the postmodern dance. The creative principle of indeterminism and the method of random action are the most important among them, which have become the basis of the musical-choreographic performances and the works of pure instrumental music of the second half of the $X X$ century. The main characteristic of the dance performances is the freedom of form formation. The composers, who worked in postmodern dance, use the aleatory forms to look for the new structural solutions of the organic combination with a free choreographic compositions with the academic cliche. The composers and choreographers consider that the main artistic task is the transition of the art work from the object into the process.

Keywords: postmoderndance, musical choreographic performance, aleatory forms.

Problem of Research. At the beginning of the 1960s, musical-choreographic art developed very much. So, there were many new trends. Postmodern dance occupied the special place among them. It showed its vivid nature and played the important role in the development of the main streams of musical and choreographic culture. Various American 
choreographers belong to its inventors. They are M. Cunningham, S. Forti, Y. Reiner, T. Brown, L. Childs, S. Pakson, D. Gordon, B. Lloyd, etc. Due to J. Cage's experiments on the study of the sound materials, the method of the random action in music and the creative experiments of the group"Fluxus", the choreographers implemented the ideas of the experiment in dance.

The second half of the XX century is the period of the formation of new compositional principles and the radical reorganization of the formation system. So, many great composers such as J. Cage, E. Brown and E. Denisov developed the fundamentals of the randomness. That process led to the emergence of new structures of musical works. It was characterized by the uncertain parameters of the composition, such as soundpermeability, timbre, duration, dynamics etc. Therefore, the performer becomes a coauthor and selects or adds some new own parameters. Randomness, uncertainty and the text mobility help the performer to find new expressiveness and to create the original version of the composition, determined by his/her artistic taste and life experience. Analysing this tendency, the musical theorists introduced many new characteristics of the music form such as "uncertain, "open", "mobile", "unlimited" and "plural".

Analysis of Researches of Topic. Recently, we can see the tendency to research tradition of the analysis of the aleatory forms in the domestic and foreign musicology. The theoretical problems, dealt with the using of the aleatory forms in the composer's practice of the second half of the XX century are studied by M. S. Vysotska, G. V. Grigoryeva [1], T. S. Kiureghyan [2], M. V. Pereverzeva [3, 4, 5], V. S. Tsenova [7]. Moreover, there is the typology of aleatory forms in the national musicology. These forms are manifested in the various composer's practices of the second half of the XX century. It has the following components mobile, variable and modular forms that differ each other in the degree of stability of the structure, the definition of the material.

Purpose of Research. The purpose of the article is to analyse the development of new mobile and modular forms in the art of dance in the second half of the XX century.

Main Part of Research. Using the principle of indeterminism, embodied in aleatory forms, composers looked for the structural solutions of the new choreography. At the end of the 1950s, M. Cunningham and J. Cage developed the choreographic aleatory techniques that determined the mobile form of dance. Therefore, a dancer and a composer were united by the idea of "randomness " as a way of creating a composition. M. Cunningham, usually, used it at all levels of creating dance to define lexis, a composition and the relationship among the co-authors.

We should note that M. Cunningham's innovative language of movements was different in his periods of the artist life. During his creative life, the choreographer applied the method of random actions and combined it with plans, drawings, tables to choose and connect the elements of a dance. All of them contributed to the creation of the new movements and their combinations, and allowed him to avoid the simple "plot" nature with the foreseeable decisions. The great innovator thought that the main idea of any dance was the experiment with the possibilities of the human body movement in time and space.

The method of the random action was popular in the compositions where the performer played the main part. The dancers could choose the elements of movements in the process of the creating a part. For example, M. Cunningham told that in the spectacle "The Secondhand" (1970) he had offered dancers the range of small hands movements and asked to perform them in any order during the 15 minutes of the dance. So, everyone could choose what they wanted to use from the proposed gamma of the movements. "I told them that they could do what they wanted, but it would be better if they did the same things 
every night" [6, p. 173]. Creating the dance "The Garland", the choreographer produced the various dance phrases, which consisted of a certain number of moves (from one up to sixty-four). According to the choreographer's plan, the scene was divided into the sixtyfour squares. Using the method of the random actions, the author determined the sequence of the movements and the location of dancers on the stage. M. Cunningham understood the dance as the water and the composition as the fluid, changeable, substance, which allowed us creating a multidimensional, polyline, flexible and mobile choreographic performance.

Indeterminism and randomness contributed to the discovering of the new ways to free dance from the academic cliches. In addition, they showed the new choreographic possibilities and allowed to restore the choreographic vocabulary by creating the unusual movements. According to M. Cunningham, the choice opened the world beyond the imagination - out of space and time. It expanded the boundaries of the stage and dance.

Since the 1960s, the American choreographers, who were the representatives of the Postmodern dance (S. Pakston, T. Brown, L. Childes) got interested in it very much.

The creative searches of the choreographers united the new musical trends and invented the new laws of the form formation in the dance. The open, modular forms got the vivid incarnations in the works of the composers. They supposed the possibility of creating the endless number of combinations. The general construction had the disassembled form and consisted of the elements, which were not connected. Musical and choreographic compositions were recorded in the music or other texts.

We can say that the aforementioned principles of constructing a musical composition first emerged in the choreographic performances. H. Cowell was the pioneer of them and wrote his music for M. Graham's dances. The composer was close to the idea of creating an "open form", a so-called "flexible" or "elastic" music. Its specificity was determined by the decision of the applied tasks. The author noted: "Anyone, who works in a dance studio, knows that dance performance is constantly changeable (from the rehearsal to the rehearsal, some or other fragments can be added or canceled. It is as an effect of improvisation" [8, p. 229].

Thus, $\mathrm{H}$. Cowell proposed to use the modular composition. It made possible to regulate the duration of sounding parts (modules) and change their sequence. The composer believed that the method of creating an elastic form was in the infancy, whereas it had the potential for the development in various areas of musical art. H. Cowell described this process in such a way: "In general, the process of making such a form can be rather simple. The minimal module (inside the form) can correspond to one choreographic phrase, section and expand ... Modules can be performed on drums, piano, orchestral instruments or any of their combinations. Thus, individual rhythm, phrase, sentence, module, or entire product can be elastic. The performance as a whole will have a form. Moreover, it can easily adapt to changes, which are necessary for the choreographer's work" [4, p. 154].

The composer liked the idea of constructing the flexible form. He applied it in instrumental music, which was not dealt with the dance. The order of the five parts in the "MosaicQuartet" (StringQuartetNo.3) (1935) was arbitrary. The most important thing was the fact that all of them sounded once. The independence of various parts was emphasized by their original texture, articulation, harmony, rhythm-melodic figures. The "Simultaneous Mosaics" (1963) consisted of 26 modules that could be performed in a random manner.

E. Brown embodied the concept of a modular, the opened form with a moving structure and a free order of material in his instrumental works of the 1960s. They were 
"AvaibleForms I" for 18 music instruments (1961) and "Avaible Forms II" for two independent orchestras, which included 98 performers (1964). Both scores contained the mobile elements. The order of music fragments (indicated by numbers, they can be arbitrarily combined and repeated) depended on the selection of the artist.

However, for the first time, E. Brown used the ideas of mobility and modularity in the musical-choreographic performances of the $1950 \mathrm{~s}$, based on the spontaneity of the executive solutions. Such compositions as "Music for Trio for Five Dancers" (1953) and " 1953 " were limited only by the time of the dance. According to E. Brown, performing the dance we can find its new forms.

The general composition "Music for Trio for Five Dancers" of E. Brown contained a number of disparate composite elements. Their performing depended on the randomness. The basis of the performance was a doubly-random method. K. Brown, a choreographer, built a dance score, based on the principle embodied by J. Cage in a series of performances "Music for Piano", where defective elements of music became the decisive ones. In the musical score "Music for the Trio", two different types of symbols were used. The first one was represented the paired groups of dance movements, the second one showed the unpaired ones. The work was monophonic and resemble to M. Feldman's graphic plays, which were only limited in time and did not have any dynamic contrasts.

The modular structures formed the basis of the "Field Dances" (1963) by J. Cage, "Story" by T. Ichiyanagi for the Merce Cunningham Dance Company. The structures of performances varied. The dancers independently chose choreographic elements each time, the musicians chose the order of the recorded sounds. T. Kosugi, P. Zamm and other composers followed the famous experimenters in the modular form in the musicalchoreographic performances.

The mobile compositions are useful for the dance art. They differ in number, the degree of mobility of sections and the variability of several elements. However, the general fundamentals of the design are unchanged.

In 1960-1990, the mobility of a language and a form became the main compositional principles in musical-choreographic performances and independent musical compositions of J. Cage, M. Feldman and E. Brown. The example of the introduction of the mobile forms in dance performance can be M. Cunningham's "108 and One8" (1991) for the dance "Interscape". The musical order of the staging consisted of two independent plays - "108", written for a large orchestra with 108 musicians and "One8" for a cello solo, which were proposed to perform together by the composer. So, it created the effect of sounding a full concert for cello solo and an orchestra. Both musical compositions as well as the choreographic series contained the indications of their temporal duration (the exact time of sounding of individual notes and chapters). The composer used it in his later works. The score showed the order of the episodes and their sound content. The principle of randomness involved the interaction of the soloist and the orchestra, music and scenography, the content of the sections.

The most part of the dance works were the musical compositions with the mobile forms that were not fixed. They were "Rainforest" by D. Tudor, "In Memoriam Nikola Tesla" by P. Olivereros, "In determinacy stories", "Variations V", "Place", "Channels / Inserts" and "Five Stone Wind" by J. Cage.

The next type of the form creating is a form, born in the process of performing. It also originated in the compositions of the Merce Cunningham Dance Company. Then it became a leader in dance performances of the late 1990s - early 2000s. So, in the Cunningham-Cage performance series Variations VI-VII we could see the foundations of 
the new forms of performances, which were accompanied by the live performance and live electronics (Live Electronics).

The live performance includes the creation and performance of musicalchoreographic compositions in real time without preliminary recording of musical fragments. The composer creates a composition during a performance. The original electronic sounds and the sounds of musical instruments transform, by the using various devices (amplifiers, filters, ring modulators, sequencers). So, we use the principle of the interaction to control the process of the sound generation in live performances.

The tendency of the creating the live performances had been popular up to the $1990 \mathrm{~s}$ in M. Cunningham's performances. In addition, it had been the leading postmodern dance. There were many bright performances. In the "Place Mesa" (1966) by G. Mammy, the bandoneon sounds was changing during the performing process by the system of electronic sound modulators. In "Rainforest" (1968), D. Tudor used an ensemble of unique electroacoustic instruments, developed by the composer. Creating "TV ReRun" (1972), G. Mammy made the dancers wear accelerometric (measuring acceleration) belts, integrated with the system of radiotelemetry. Music depended on the speed of the movement of dancers.

P. Zamm, a jazz trombonist and virtuoso, had been playing the free jazz for a long time. Its core was the free improvisation. He embodied those ideas in many works, including the famous musical and choreographic performances with T. Brown. His dance compositions ("Lateral Pass: Sci-Fi", "Lateral Pass: Song VI", "Lateral Pass: Song IV") were based on the variation and improvisation. The works represented the ensemble improvisation without any rules and instructions. It was characterized by the random choice. The common link was the similar elements of the musical material, which were based around the basic sounds of the composer. The mobility of the text allowed the performer to choose and create a unique sound and structural appearance of the work during the performance. The uncertainty contributed to the searching for new means.

The typical examples of form creating, based on improvisation were the dance performances of the Palindrome Dance Company, where compositions were formed in the process of performing. The performance "Seineholhe Form" is a common work of the dance company "Palindrome" and the Centre of the Experimental Music and Intermedia of the University of the Northern Texas. The sound and images of the project were designed interactively. So, the authors controlled the music series and provided the work of the interactive system and staged the dance. In the process of performing, the choreography was under the influence of the live sound generation of sound.

The wide spreading of digital interactive technologies in postmodern dance deals with the emergence of the accessible sensor technologies and echo tracking applications (Eycon, Eyes Web, Big Eye). The problem of creating an improvisational form also concerns the interaction of sound and motion in real time. Due to the special connectivity of the sound and the gesture we can see the sense of the integrity of the play. Despite the supposed chaos of the sound series it develops.

The controlled sound startup is one of the simplest and most frequently used methods in interactive systems. The intensity of the gesture can affect the strength and height of the sound, the choice of timbre and the general dynamic plan. The dancer can control rhythm of the soundtrack. The application of this principle in digital performance deals with the consistent reproduction of pre-recorded audio. At the step of the preparation, the choreographer and the composer select the pre-recorded sounds. Then the ready 
material is compiled and performed by using the certain movements, fixed on the sound events.

In the performance, the control over the sound events is a continuation of the gesture control. So, the changes in the parameters of movements (speed and intensity) can be compared with the sound transformations. These principles are based on the technique of granular synthesis, which is widely used in musical-dance systems. The granular synthesis means the segmentation of the recorded sound into the small sound "granules".

The difficult relationship between a gesture and a sound response is connected with the development of a special model of the stage behaviour. Certainly, the complex calculations can simulate the sounds of various materials (water, stones, and abstract textures). Keeping the object with a built-in tilt angle sensor, the dancers can control the parameters of the granular synthesis and create different sound effects.

The interactive systems can apply various measurements of the physiological parameters. It means that the physiological processes (muscle work, heartbeats, breathing, brain activity) can be transformed into the form of electrical signals. They generate the sound by the technology of biological feedback.

Conclusions. Thus, there are specific methods for creating / writing a musical composition and the principles of forming in the postmodern dance. The creative principle of indeterminism and the method of random action are the most important among them, which have become the basis of the musical-choreographic performances and the works of pure instrumental music of the second half of the XX century. The main characteristic of the dance performances is the freedom of form formation. The composers, who worked in postmodern dance, use the aleatory forms to look for the new structural solutions of the organic combination with a free choreographic compositions with the academic cliche. The composers and choreographers consider that the main artistic task is the transition of the art work from the object into the process.

\section{Література}

1. Высоцкая М. С. Музыка XX века: от авангарда к постмодерну : учеб. пособие. Москва : Московская консерватория, 2011. - 440 с.

2. Кюрегян Т. С. Алеаторика (Глава XII) // Теория современной композиции / отв. ред. В. С. Ценова. Москва, 2005. - С. 412-430.

3. Переверзева М. В. Алеаманиякомпозиторовнью-йоркскойшколы // Израиль XXI: музыкальный журнал. URL Режим доступа : http://www.2lisrael-music. com/ Aleamania.htm.

4. Переверзева М. В. Модульная форма в музыке и метод еёанализа // Общества теории музыки. -2013 . - № 1. - C. 152-178.

5. Переверзева М. В. Свободная алеаторика и строгая форма - две вещи несовместные? // Израиль XXI: музыкальный журнал. URL Режим доступа : http://www.2lisrael- music.com/ Svobodnaya_aleatorika.htm.

6. Суриц Е. Я. Балет и танец в Америке: очерки истории. Екатеринбург : Изд-во Уральского университета, 2004. - 392 с.

7. Ценова В. С. О современной систематике музыкальных форм // Laudamus. К 60-летию Ю. Н. Холопова. Москва, 1992. - С. 107-113.

8. Essential Cowell: Selected Writingson Music. Edited by Dick Higgins. Kingston: McPherson

\section{Referens}

1. Vysockaya M. S. Muzyka XX veka: ot avangarda k postmodernu : ucheb. posobie. Moskva : Moskovskaya konservatoriya, 2011. - $440 \mathrm{~s}$.

2. Kyuregyan T. S. Aleatorika (Glava XII) // Teoriya sovremennoj kompozicii / otv. red. V. S. Cenova. Moskva, 2005. - S. 412-430.

3. Pereverzeva M. V. Aleamaniyakompozitorovnyu-jorkskojshkoly // Izrail XXI: muzykalnyj zhurnal. URL Rezhim dostupa : http://www.21israel-music. com/ Aleamania.htm.

4. Pereverzeva M. V. Modulnaya forma v muzyke i metod eyoanaliza // Obshestva teorii muzyki. 2013. - № 1. - S. 152-178. 
5. Pereverzeva M. V. Svobodnaya aleatorika i strogaya forma - dve veshi nesovmestnye? // Izrail XXI: muzykalnyj zhurnal. URL Rezhim dostupa : http://www.21israel- music.com/ Svobodnaya aleatorika.htm.

6. Suric E. Ya. Balet i tanec v Amerike: ocherki istorii. Ekaterinburg : Izd-vo Uralskogo universiteta, 2004. - $392 \mathrm{~s}$.

7. Cenova V. S. O sovremennoj sistematike muzykalnyh form // Laudamus. K 60-letiyu Yu. N. Holopova. Moskva, 1992. - S. 107-113.

8. Essential Cowell: Selected Writingson Music. Edited by Dick Higgins. Kingston: McPherson

Одержано статтю: 17.10 .2018

Прийнято до друку: 31.11 .2018

\section{УДК 808.5}

DOI:10.15330/esu.14.51-57

\author{
Лідія Ткаченко, \\ доктор педагогічних наук, доцент, \\ Харківський національний педагогічний ніверситет \\ імені Г.С. Сковороди (м. Харків, Україна) \\ Lidiia Tkachenko, \\ Doctor of pedagogical sciences, Associate Professor, \\ H.S. Skovoroda Kharkiv National Pedagogical \\ University (Kharkiv, Ukraine) \\ lidiyatkachenko45@gmail.com
}

\section{УКРАЇНСЬКА АКАДЕМЮЧА РИТОРИЧНА ШКОЛА}

\section{UKRAINIAN ACADEMIC RHETORIC SCHOOL}

У статті йдеться про становлення та розвиток в Украӥні академічної риторичної иколи, ио трансформувала кращі надбання викладання гуманітарних дисииплін 3 братських икіл та колегіумів. Периі украйнські університети напрачювали автентичну парадигму передачі знань, яка вирізнялася не лиие трунтовними знаннями викладачівлекторів, а й спиралася на традииійні для наиої освітньої системи приниипи: народність, доступність, природовідповідність тоцо. У статті доведено, ио академічні ритори використовували власний досвід побудови навчальних курсів, прагнули до запроваджения діалогічних методів навчання, активно аналізували зарубіжний досвід, але передавали знания з опорою на ментальність украйнського студентства. Зазначено, ио значний внесок в розвиток риторики як навчального предмета внесла університетська освіта. Вивчення історії становлення академічного красномовства доводить, ио українські викладачіритори створили непересічну систему взаємодії викладач - студент, щзо передбачає паритетні конструктивні взаємини у навчальному прочесі.

Ключові слова: риторика, університет, освіта, система, підручники, методика.

The article deals with the formation and development of an academic rhetoric school in Ukraine that transformed the best achievements of teaching humanitarian disciplines from fraternal schools and colleges. The first Ukrainian universities developed an authentic paradigm of transfer of knowledge, which was different not only in the sound knowledge of lecturers, but also based on the traditional principles of our educational system: nationality, accessibility, natural conformity, etc. The article proves that academic rhetoricians used their own experience in constructing training courses, aimed to introduce dialogical teaching methods, actively analyzed foreign experience, but transferred knowledge based on the mentality of Ukrainian students. It is noted that university education made a significant contribution to the development of rhetoric as a subject of study. Famous teachers, public figures, linguists, and rhetoricpractitioners developed theoretical and practical principles of rhetoric. Development of the courses of the theory of literature was based on scientific researches of $M$. Dragomanov, M. Kostomarov, K. Zelenetsky, O. Potebni, I. Ryzhsky, I. Sreznevsky and others. The textbooks of 